\title{
Moral considerations concerning income inequality
}

\begin{abstract}
Author:
Jurjen P. de Vries ${ }^{1}$

Affiliation:

${ }^{1}$ The Theological University of the Reformed Churches at Kampen, the Netherlands

Correspondence to:

Jurjen de Vries

Email:

jurndevries@tukampen.nl

\section{Postal address:}

Heiligenbergerweg 116,

3816 AM Amersfoort, the

Netherlands

\section{Dates:}

Received: 05 June 2014

Accepted: 22 Sept. 2014

Published: 28 May 2015

How to cite this article: De Vries, J.P., 2015, 'Moral considerations concerning income inequality', In die Skriflig 49(1), Art. \#1846, 9 pages. http://dx.doi. org/10.4102/ids.v49i1.1846

\section{Copyright:}

(c) 2015. The Authors.

Licensee: AOSIS

OpenJournals. This work is licensed under the Creative Commons Attribution License.
\end{abstract}

\section{Read online:}

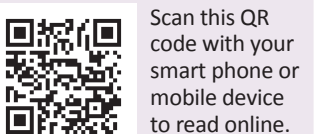

The income inequality evident today has reached ethically unwarranted levels. In the Old and New Testament the Bible teaches us that disparity in wealth ought to meet the norms of justice and equity. Differences in income must be proportional to differences in the workers' performance and the responsibilities they assume. Employers and trade unions have the duty to ensure that these boundaries are respected. The government's obligation is to take measures against the abuse of power monopolies, but it does not have to pursue income equality as such. Finally, where greed still rules society, Christians have the task to model a different life.

In die hedendaagse samelewing kan aansienlike inkomsteverskille nie eties verantwoord word nie. In sowel die $\mathrm{Ou}$ as Nuwe Testament leer die Bybel ons dat verskille in inkomste aan die norm van regverdigheid en billikheid moet voldoen. Inkomsteverskille moet in 'n sinvolle verhouding tot die verskil in prestasie en verantwoordelikheid staan. Werkgewers en vakbonde moet in hierdie opsig die nodige grense in stand hou. Die owerheid kan maatreëls instel teen die wanpraktyke van magsmonopolieë, maar nie teen inkomste-ongelykhede as sulks nie. Wanneer hebsug die botoon in 'n samelewing voer, is dit die taak van Christene om 'n eie lewenstyl te handhaaf.

In de hedendaagse maatschappij zijn de inkomensverschillen groter dan ethisch verantwoord is. Het Oude en Nieuwe Testament van de Bijbel leren dat financiële verhoudingen moeten voldoen aan de normen van rechtvaardigheid en billijkheid. Inkomensverschillen moeten in redelijke verhouding staan tot het verschil in prestatie en verantwoordelijkheid. Werkgevers en vakorganisaties moeten hier de verantwoorde grenzen bewaken. De overheid neemt maatregelen tegen misbruik van machtsmonopolies ten eigen bate, maar voor haar is nivellering niet een doel op zich. En als in de maatschappij de hebzucht nog de boventoon voert, is het de taak van christenen hier een eigen stijl te vertonen.

\section{Introduction - Question and method}

In January 2014 income inequality suddenly became a topic of widespread interest. Not only was it the most important subject broached by the World Economic Summit in Davos, it also occupied a central place in president Barack Obama's State of the Union address. Over the course of the last decades, income inequality has grown both in the developed as well as the developing parts of the world. The science of economics can explain this phenomenon and even justify it as well as point to its pros and cons. The leading principle for economics is that of utility. The question is, however, whether income inequality may also be evaluated from the perspective of good and evil - of what is and is not moral. ${ }^{1}$ This is the terrain proper to ethics.

This article will address income inequality from an ethical perspective. The argument made here does not, after all, amount to a plea against all income inequality. ${ }^{2}$ Since all people have been created according to the image of God, they are in essence equal (O'Donovan 2005:40). This makes it necessary for us to offer a brief defence of income inequality. In this vein, it is worth noting that the ideal of equal compensation does not match the reality we encounter in our human society. ${ }^{3}$ Since people are not by nature inclined to do what is good, they have to be stimulated to a better performance. One such stimulus is the prospect of a higher income. In fact, without this financial stimulus, society could not function well at all. ${ }^{4}$

\footnotetext{
1.The considerations in this article are for practical reasons restricted to income inequality. For an economic critique of capital inequality see Piketty (2013).

2.This is, however, done by J-J. Rousseau (1992). Cf. O'Donovan (2005:47): 'There is no moral significance in distributing goods equally as such.'

3.'Absolute equality is not a meaningful social goal' (Niebuhr 1957:14).
}

4.'After all, those who work hard should be rewarded, and have to be, if they are to make the efforts and the investments from which all benefit. Some inequality is indeed inevitable' (Stiglitz 2013:7). 
The question is, however, whether the disparity between incomes may become too great, and whether the discipline of ethics has anything to say in this regard. This article will argue that the income inequality in our present-day society has crossed the boundaries of what is ethically warranted and has, in fact, damaged the quality of society.

Following the method of theological ethics, the considerations in this article for distinguishing between what is good and bad will be largely informed by the wisdom offered in Holy Scripture. 'If we believe in a reality consciously created by a living God, then that reality is itself stamped by that loving, caring God' (Goudzwaard et al. 2007:182). ${ }^{5}$ For this reason, the principles of love, justice and good care for all that exists, are of great importance. Whilst the laws of economic utility indeed have their importance, they nevertheless cannot offer the final word.

Firstly, a description of the current status of income inequality will be offered, focusing in particular on the United States, the United Kingdom and the Republic of South Africa. Then the biblical perspectives offered in the Old and New Testament will be presented. On this basis an ethical standpoint, concerning a responsible income disparity, will be formulated. This article will also outline the guidelines for society that follow from this, examine the respective responsibilities of employers and employees, and inquire into the task and opportunities the government has for achieving a more just income distribution. The final section will demonstrate how the Christian church can model a different life.

\section{The current status in the United States, the United Kingdom and the Republic of South Africa}

If we disregard the emerging economies, ${ }^{6}$ income inequality must be said to be the greatest in the USA (Stiglitz 2013):

By 2007, the year before the crisis, the top 0.1 percent of America's households had an income that was 220 times larger than the average of the bottom 90 percent [...] Over the last three decades those with low wages (in the bottom 90 percent) have seen a growth of only around 15 percent in their wages, while those in the top 1 percent have seen an increase of almost 150 percent and the top 0.1 percent of more than 300 percent. (pp. 7, 9)

In an article on 'the rich and the rest' on 20 January 2011, The Economist (2011) noted:

In America income inequality began to widen in the 1980s largely because the poor fell behind those in the middle. More recently, the shift has been overwhelmingly due to a rise in the share of income going to the very top - the highest $1 \%$ of earners and above - particularly those working in the financial sector.

\footnotetext{
5.Goudzwaard et al (2007) observe in this context: 'Secularized Westerners often think that norms or values are simply the outcome of certain agreements made between people. But the Christians among them know differently.'

6.Along with the USA, the greatest income inequality is found in South Africa, Brazil and China.
}

Many Americans are seeing their living standards stagnate, but the gap between most of them has not changed all that much.

Two years later, on 21 September 2013, The Economist (2013) used new statistics to conclude:

Most of the growth is going to an extraordinarily small share of the population: $95 \%$ of the gains from the recovery have gone to the richest $1 \%$ of people, whose share of overall income is once again close to its highest level in a century. The most unequal country in the rich world is thus becoming even more so.

This same trend has been noted by the well-known theologian and social activist Ronald Sider. He considers it (Sider 2005):

... very disturbing $[\ldots]$ that the gap between rich and poor is increasing again in very wealthy countries, especially the U.S. and U.K. - the two wealthy market economies with the greatest reliance on the market. In the U.S., the gap between the rich and poor has grown enormously in the last thirty-plus years. (p. 139ff.)

The same trend can be observed within individual companies. Joseph Stiglitz (2013) has drawn attention to:

... the huge gap between CEO pay and that of the typical worker - more than 200 times greater - a number markedly higher than in other countries (in Japan, for instance, the corresponding ratio is 16 to 1 ) and even markedly higher than it was in the United States a quarter century ago. (p. 26)

This dramatic growth in income inequality occasioned the International Labour Organization to issue a warning in June 2013 (Babones 2013).

Stiglitz (2013) accounts for this phenomenon in terms of power inequality. The present situation is as the richest $1 \%$ wants it to be: wealth leads to power, and power in turn produces wealth. American senators and representatives are elected thanks to donations from the top $1 \%$. They are very much aware that, at the close of their political career, they will be handsomely rewarded by this $1 \%$ if they look after their interests. Stiglitz's objections are not only moral in nature (i.e. the American notion of 'fair play' is compromised), but also purely economic. The accumulation of this much money and power by the 'happy very few' decreases general welfare, leads to instability and annihilates the very notion of democracy. ${ }^{7}$

In respect to the UK, which has already been mentioned in passing above, Skidelsky and Skidelsky (2012), citing the UK Office of National Statistics, reports the following: ${ }^{8}$

In Britain, the basic pay of CEO's in FTSE top companies was 47 times an average worker's pay in 2000; by 2010, it was 81 times. Since the late 1970s, the income of the richest fifth has increased [...] four times as fast [as that of the poorest fifth]. (p. 30ff.)

7 .... as our economic system is seen to fail for most citizens, and as our system seems to be captured by moneyed interests, confidence in our democracy and in our market economy will erode along with our global influence' (Stiglitz 2013:xii).

8.See also Stiglitz (2013:xxiii): 'Thirty years ago, inequality in Britain was just average for the advanced industrial countries. But now it is second only to the United States. 
The middle class, who has always formed the very basis for social stability, increasingly has to forego financial growth.

South Africa is characterised by sharp inequalities in the distribution of income, property and opportunities, mainly to the detriment of black people, as an inheritance of the apartheid period. After the introduction of a democratically elected government in 1994, political and human rights transformations have taken place, but no such transformation has yet taken place in the socio-economic sphere. The precarious situation in which large numbers of black people and those of mixed race find themselves has become more burdensome. Sampie Terreblanche (2002) concluded:

While the income of the richer income groups - and especially the richer 25 per cent of the black people - increased quite dramatically over the last eight years [1994-2002], the per capita income of the poorer two thirds of the population (mainly Africans and coloured) has declined further [...] Consequently, the gap between the income of the top 20 per cent of households and the lower 60 per cent of households has become much greater. (p. 32)

In spite of this, Terreblanche (2002:400) did observe a shift over the past 30 years: from a race-based to a class-based skewed distribution of income. This has not changed in the years after 2002. Leibbrandt, Finn and Woolard (2012) conclude from statistical data:

\begin{abstract}
... South Africa's high aggregated level of income inequality increased between 1993 and 2008. The same is true of inequality within each of South Africa's four major racial groups. A major drive of this situation was shown to be the increased share of income going to the top decile. (p. 32)
\end{abstract}

\section{Economic objections to great income inequality}

Income inequality is often defended with the argument that it stimulates people to work harder and perform better. Restricting this inequality, so it is argued, would weaken this stimulus and come at the cost of economic growth and labour opportunities. There is a kernel of truth in this, and this is also why this article does not plead for a total levelling of incomes. ${ }^{10}$ What measure of inequality is optimal? When are incomes sufficiently unequal to stimulate and drive people to get the most out of themselves, whilst still protecting a sense of social justice and providing hope of upward social mobility?

There is in any case also a negative side to the disparity, and this negative side becomes all the worse as the disparity widens. When incomes are too disparate, this is detrimental to the work ethic in a company. It negatively impacts productivity and innovation. The negative effects extend also to society as a whole. According to Paul Krugman (2011), an extreme concentration of income is:

\footnotetext{
9. In 2001 , the richest $20 \%$ received $72.2 \%$ of the total income; the poorest $60 \%$ received $10.6 \%$ (Terreblanche 2002:33).

$10 . '$ I and, as far as I know, more progressives - do not argue for full equality. We realize that that would weaken incentives. [He then adds the question:] How seriously would incentives be weakened if we had a little bit less inequality?' (Stiglitz 2013:98)
}

... incompatible with real democracy. Can anyone seriously deny that our political system is being warped by the influence of big money, and that the warping is getting worse as the wealth of a few grows ever larger?

Meeks (1989) also explains:

The more the few gain power and privilege through property rights at the expense of the many, the more democracy is injured and no longer counted on as the shape of our future. (p. 5)

Sacks (2003) describes more negative effects:

Typically, financial deprivation goes hand in hand with social poverty: depressed neighbourhoods, atrophying communities, high crime, drug-dealing, failing schools and overextended social services. (p. 108)

Oxfam International (2014) reached the same conclusion in its report 'Working for the few - political capture and economic inequality', prepared for the World Economic Forum in 2014:

Some economic inequality is essential to drive growth and progress, rewarding those with talent, hard earned skills, and the ambition to innovate and take entrepreneurial risks. However, the extreme levels of wealth concentration occurring today threaten to exclude hundreds of millions of people from realizing the benefits of their talents and hard work. Extreme economic inequality is damaging and worrying for many reasons: it is morally questionable; it can have negative impacts on economic growth and poverty reduction; and it can multiply social problems. (p. 2)

Basing themselves on 30 years of scholarly study, Richard G. Wilkinson and Kate Pickett (2009) concluded that greater inequality affects not just the poorest, but in fact the majority of the entire population. Furthermore, it has emerged that the smaller the income inequality in a particular community, the less social unrest, illness and crime is found in it. Whether it is teen pregnancy, suicide, crime, illiteracy, obesity or infant mortality, in each of these categories the countries with a smaller disparity in income between the richest and poorest sectors of the population perform better. Additionally, these countries experience greater social cohesion and social mobility. Everyone, both rich and poor, benefits when there is less inequality. In the end, all people - including the rich in these countries are happier than they are in countries with a greater measure of inequality (Wilkerson \& Pickett 2009). ${ }^{11}$

If people are content when they see that they can live a decent life from the fruit of their labour, society looks altogether different compared to the way it would if these same people abandon themselves to the pursuit of infinite profits. Therefore, many agree that the great increase in income inequality is not a positive development. What is lacking, however, is a sense of leadership in society (i.e. an 'invisible hand') to head it in a better direction. This makes personal responsibility all the more important, fed by values that are higher than mere personal interest. Where personal

11.Cited via a column in NRC Handelsblad by F. Timmermans (2011), at that time member of the House of Representatives in the Netherlands. 
responsibility fails, there social partners and lawmakers have their own responsibilities they must assume.

\section{The contribution of theological ethics - guidelines from the Old Testament}

The disadvantages we noted above already speak volumes. Nevertheless, we can dig even deeper by examining what values and norms ought to apply in this area. Values and norms are important for the quality of human society. Theological ethics views the Bible as an authoritative norm for values and norms. It further adds that living according to biblical norms is important for going through life with a clear conscience.

The Bible offers no direct answers to present-day economic questions, but it points us in a certain direction where we must nevertheless be careful to take into account the changed circumstances in which we live (Meeks 1989:3). This latter point is particularly relevant when it comes to the Old Testament. Although it addresses the people and nation of Israel of some 3000 years ago, without it the Christian tradition of reflection on social justice still remains unimaginable (De Bruijne 2011):

Such books as Proverbs and Ecclesiastes in particular clearly demonstrate that, in order to know good and evil, you should also simply open your eyes and look at the reality around you. You do not have to derive everything in one way or another from the Bible [...] A large part of the Christian life is a matter of practical wisdom, which is entirely amenable to a certain realism. (p. 82, [author's own translation])

The Old Testament does not oppose wealth as such, but rather views it as a blessing from God. It does, however, warn us about the dangers the pursuit of wealth involves and condemns those who try to become rich at the cost of the poor:

- 'Do not slave to get wealth; be sensible, and desist. Before you can look around it is gone!' (Pr 23:4-5). ${ }^{12}$

- 'No one who loves money can ever have enough, and no one who loves wealth enjoys any return from it. This too is futility.' (Ec 5:10).

- 'Woe to him who builds his palace on unfairness [...] giving [his countrymen] no wage for their labour!' (Jr 2:13).

- The prophet Amos denounces those who live in wealth whilst oppressing the poor (Am 3:9-10; 3:12, 4:1).

- Employers are commanded to give their labourers an honest wage and to pay them on time (Dt 24:14-15).

Numerous regulations in the Mosaic Law are intended to protect the poor and to prevent the accumulation of wealth. 'The laws that spring from the Torah are meant to preserve the political and economic equality that Yahweh means to create as deliverer of Israel' (Meeks 1989:84). Although no

12.Biblical quotations are all taken from The Revised English Bible biblical passage holds up total income equality as a norm, the Old Testament still is surprisingly egalitarian.

The British theologian Christopher Wright (2004) once asked:

Do we not still need the severity of the Old Testament's strictures against the subtle, as well as the blatant, idolatries of our age and cultures? [He responded:] Christians are often as prone as Israel to relegate God unconsciously to salvation and Sundays, while we serve the golden calves and Baals of materialistic, consumerist culture in 'real life'. Discernment of idolatry is a crucial task, a prophetic responsibility, and frequently a costly undertaking for those who expose the idols of any culture. Do we not still need the Old Testament's uncompromising critique of all that oppresses and those who callously 'trample on the heads of the poor' (Amos 2:7; Mic.3:2-3 is even more bloodcurling)? If the sin of Sodom was to be 'arrogant, overfed and unconcerned' and callously unhelpful to the poor and needy (Ezek. 16:49), then large sections of the Christian church (and especially in the West) are dwelling at ease, not in Zion, but in Sodom. Israel was called to reject and resist these things. There is surely a battle for the church as well. (p. 348ff.)

\section{The contribution of theological ethics - guidelines from the New Testament}

In the New Testament a number of the Old Testament directives reappear. For instance, the apostle Paul warns those who want to be rich against the temptations into which they may fall, and for the foolish and harmful desires that plunge them into ruin and destruction (1 Tm 6:9). The New Testament also includes the warning not to hold back wages (Ja 5:4). Jesus warns his disciples not to pursue riches: 'You cannot serve God and Money' (Mt 6:24). Worries about material things may not rule our life (Mt 6:31-34; Lk 12:29-32). Paul places the money-grubber on the same level as the adulterer (1 Cor 5:11, 6:10; Eph 5:5). Those who work must receive a living that allows them also to have something to share with the needy (Eph 4:28; 2 Cor 9:8). ${ }^{13}$ The New Testament offers no reflection on the most suitable economic system, but it does contain pointers for how we are to live.

The parable of the workers in the vineyard (Mt 20:1-16) is important for the topic this article addresses. The owner of the vineyard hires labourers at different times of day - the first works for 12 hours, the last only for one hour. In spite of this, they all receive what had been agreed upon with the first. For the owner the compensation was not set by labour performance, but he wanted to give each of them a living wage (Van Bruggen 1990:371). It is furthermore emphasised that the owner did not owe this to them, but that he gave all labourers the same compensation out of the goodness of his heart.

13.Calvin writes in his commentary on Genesis 30:29: 'Ainsi, le salaire a quelque chose de sacré: il atteste que Dieu est à l'oeuvre pur sauver et nourrir ses enfants; il est le gage de son a que Dieu est à looune pur sauver et nour ses enfants, il est le gage de son amour, le temolgnage de sa provide'ce, le signe materiel de sa souverainité surtousles actes journallers des promes' 'So, the loan had something holy. It shows that God is going to save and feed his children; it is the pledge of his love, the evidence of his providence, the material sign of his sovereignty about al the daily deeds of men'] (as cited in Biéler 1961:416; [author's own translation]). 
'Equality' (Greek: isotès) is also the criterion Paul maintains when he urges the church in Corinth to offer financial support to the church in Jerusalem: '[I]t is a question of equality. At the moment your surplus meets their need, but one day your need may be met from their surplus. The aim is equality.' Right after that, Paul points them to the distribution of manna during Israel's desert sojourn (Ex 16), where no one had either too much or too little (2 Cor 8:14-15). This does not mean each person gathered just as much as the other. Instead, everyone had enough according to his needs - the distribution was just and fair.

\section{Teunis van Spanje (2009) comments on this passage:}

\begin{abstract}
With his use of the word isotès [Paul] does not propose a kind of biblical socialism in which the differences between poor and rich are levelled out, where everyone shares equally in the available means. Paul only means to say that the surplus of the one ought to take away the shortcoming experienced by the other [...] Surplus is fine, but only as long as others do not suffer want. (p. 220, [author's own translation])
\end{abstract}

Against this backdrop, the wealth seen in the Western world indeed raises many questions.

\section{Consequences for ethics}

What lessons can we draw from the biblical data above? First of all, performance and efficiency ought not to be the only determining factors when it comes to income levels. It is also important to meet non-economic norms, like justice. If we measure society today by that norm, it is evident that self-interest has been given greater power than God's will actually allows. In order to withstand this power of attraction, it is necessary to develop norms that are based on justice and equity, and at the same time to respect the differences between individual people. Concretely this means that:

1. account must be taken of what people need for their livelihood;

2. account must be taken of differences in performance;

3. the goal ought to be for all to develop their talents maximally.

Those who respect these norms can have a clear conscience.

The first norm points to the minimum: those who devote themselves fully to the labour process as salaried employees, have a right to an income by which they can support themselves and their children, and further have something to give away. It is a matter of social justice. ${ }^{14}$

Some claim that need ought to be the only criterion. This notion was defended in particular by the followers of Karl

14.I I feel absolutely confident, however, that the biblical understanding of "economic equality", or equity, demands at least this: God wants every person and family to
have equality of economic opportunity, at least to the point of having access to the have equality of economic opportunity, at least to the point of having access to the
resources necessary (land, money, education), so that by working responsibly they resources necessary (land, money, education), so that by working responsibly they
can earn a decent living and participate as dignified members of their community. can earn a decent living and participate as dignified members of their community. This kind of equality of economic opportunity is [...] a clear, powerful biblical
demand - which, if implemented in our world, would help correct a terrible evil that still persists.' (Sider 2005:xiv). Meeks (1989:xi) is critical of the fact that human livelihood is left out of the theory and practice of the market economy.
Marx. The programme of the Socialist Workers' Party of Germany pled for a just distribution of workers' wages. The programme further explained that the final goal was for society to be able to proudly fly in its mast the motto: '[F]rom each according to his ability, to each according to his needs!' (Marxists Internet Archive n.d.).

Difference in people's needs, however, is only one aspect of justice, and also other differences should be taken into account. Not everyone is equal in talent, zeal, persistence, execution of plans and willingness to sacrifice. Similarly, one person may have greater responsibilities than another, or incur greater costs in his or her education. Such differences may, to a reasonable degree, be expressed in different incomes. The clause to a reasonable degree is necessary, because in these differences a role is also played by aspects such as talent, character and surroundings, which people do not obtain themselves, but simply receive. A maximal development of the talents found in each person is guaranteed best by rewarding a person's labour according to its quality, degree of difficulty and importance, yet within reasonable boundaries vis-à-vis those who are less privileged.

The norm of equity does not demand that all differences as such be eradicated, but rather all unjust differences. Incomes may differ more than equity warrants by the abuse of power, for example as the result of a monopolising position or unfair discrimination according to sex, race or ethnicity. This must be resisted. Rich and poor are soon divided, not only by a difference in welfare, but also in power. For that reason the economic order must be structured such that the basic positive rights of the poor are honoured as much as possible without encroaching more than is necessary upon the economic freedom of the others.

It is worth noting that these ethical insights are not specifically Christian. This article refers in this context to the Aristotelian virtues of wisdom, courage, temperance and modesty. ${ }^{15}$

If these norms are neglected, results are sure to follow. Excessive income inequality that many experience as unjust, damage the cohesion of society and lead to fragmentation as well as social and moral indifference. It was not without reason that the document Global Risks for the World Economic Forum identified income disparity as one of the most worrying of issues. 'Widening gaps between the richest and poorest citizens threaten social and political stability as well as economic development' (World Economic Forum 2014:14). It has a squeezing effect on the middle classes in developed economies.

This is why the reformer, John Calvin, gave so much attention to economic questions when he sought to establish a Christian society in Geneva. He not only mobilised himself for the creation of labour opportunities, but also strove to ensure that those who did normal work would receive sufficient 15. It was Aristotle who imprinted upon the Western mind the idea that the essence
of justice was equality [... and that equality] cannot be an univocal term with a quantitative application' (O'Donovan 2005:33). 
compensation. He pled repeatedly for wage increases. When the city council established upper income limits in order to combat inflation, the pastors were opposed. In the interest of a harmonious society, Calvin urged that salary contracts be used and that people have the opportunity to seek arbitration in case of conflict (Biéler 1961:158, 162, 425). The most important norm Calvin applied in all these things can be summarised as the rule of reciprocity and the rule of love. Both are closely related to the golden rule of Matthew 7:12 (Biéler 1961:464): 'Treat others as you would like them to treat you.

\section{Recommendations for social relationships}

When we speak of personal incomes, we have to distinguish between profit incomes gained by someone who engages in business at his own risk and whose incomes therefore fluctuates, and incomes gained on the basis of a labour contract, which are essentially guaranteed, although they may still include certain variable elements.

There is no ethical objection to a high profit income, provided that the profit was gained honestly without, for example, the exploitation of the employees. This is the reward for the risk assumed. At the very most one might ask, especially if the entrepreneur provides goods or services that are socially beneficial, whether these goods or services might not be offered at a lower price so as to make them more readily accessible, with the entrepreneur being content with the possible decrease in profit, which may follow as a result. A monopoly position does not justify unreasonable profits. For the rest, the entrepreneurs may be encouraged to distribute liberally to those in need from their growing wealth. ${ }^{16}$

This article will focus on incomes based on labour contracts. Within a single company, there may be great differences as mentioned earlier, the disparity has been growing over the last 20 years. Theological ethics does not have the task to establish quantitative norms. Nevertheless, should our point of departure not be that the difference between highpaid and low-paid employees should be proportional to their respective contributions in the company's production? Also, can a 1:1000-ratio, for example, then still be justified? In his commentary on Isaiah 65:23, Calvin writes that the boss - morally speaking - does not have a greater right of disposal than his employees over the fruits of their common labour. Both live by the grace of God. Similarly, in a sermon on Deuteronomy 15:11-15, he remarks that the Bible may not provide a quantitative key for the distribution between lords and servants, but that equity and justice should still function as the golden rule (Biéler 1961:417, 419).

Therefore, if the good performance of a company is reason enough to provide extra compensation for the top executives, the same ought to apply to the rest of the personnel. After all, they all worked together in producing the attained

16.A good example is the Bill and Melinda Gates Foundation. results. ${ }^{17}$ Both the supervisory board and the unions have the responsibility to see to it that equity is maintained in this respect. When the top receive extra rewards whilst, for economic reasons, a pay raise is denied to those who are employed under the terms of a collective bargaining agreement, this is nothing less than personal enrichment at the cost of others. Proponents of such executive compensation often appeal to the market conditions in order to justify them. The first comparative norm, however, should not be what a person earns somewhere else, but the ratio within that company. In fact, one may question whether a person whose primary motive is money really has a suitable mentality for leadership in a business, since it has not only economic, but also such as social targets. Directors ought to give greater weight to the interests of their company and of their employees than to their own financial interests. Therefore, the acceptance and promotion of a wider and moral understanding of the aim of business is necessary.

As already stated, ethics must be very careful in establishing strict quantitative norms. We do want to propose one consideration, however. Income inequality should be allowed to be greater in business than for functions paid from the public coffers, for which taxes are of course levied on the government's authority. ${ }^{18}$ In non-profit organisations, the disparity must be narrower than it may be in commercial business (Conijn 2011). ${ }^{19}$

Yet, because greed often exercises a greater power over people than the voice of their conscience does, the business community would do well to develop codes in every sector for what might be considered reasonable there, whilst the supervisory board is charged with the responsibility to enforce these codes. ${ }^{20}$ Through transparent reporting procedures, compliance ought to be publicly verifiable too. If there is no code in place, transparency will in the end only lead companies to start outbidding each other.

\section{Recommendations for the government's task}

Norms are respected by way of self-regulation, social pressure and government legislation. On a more fundamental level, the moral quality of acts depends on the dominant values and convictions harboured by the people themselves. By means of participation in public debate, Christians can influence these values. Rules become less necessary as these norms incite people to good behaviour, and as they appropriate these values and the resulting norms for themselves. If economic activity is not carried out in accordance with the norm of justice, the government has the call to exercise its authority. After all, it has the task to restrain lawlessness amongst men

17. . [O]ne can't really separate out any individual's contributions from those of others (Stiglitz 2013:97).

18. Recently, the Netherlands has enacted a maximum income of ca. $€ 230,000(130 \%$ of the salary of ministers) for those whose salary comes from public funds.

19.In Japan the ratio in business is 16:1 (Stiglitz 2013:26). On 24 November 2013 a referendum was held in Switzerland to limit the ratio between the highest and the lowest salaries to $12: 1$. This proposal was rejected by a $65 \%$ majority of the voters.

20.This is comparable with the Code-Tabaksblat in the Netherlands (Wikipedia n.d.) 
(cf. Belgic Confession, art. 36). How can the government do this, and how far does its responsibility extend?

Legislation protects the acquisition and possession of property, even when that property is obtained in morally questionable ways. The rich especially benefit from this protection. It is just as necessary, however, to protect the poor against the power of the rich, for 'an equitable distribution will not emerge naturally from the free working of the market alone' (Sacks 2003:118). The market is 'good at creating wealth but not at distributing it. It encourages certain virtues but undermines others. It has social consequences that are not always benign and sometimes disastrous' (Sacks 2003:87ff.). We cannot leave it to the market to take care of its own consequences. Markets have no inherent moral character (Stiglitz 2013:xiii). Consequently, we need governments that can act with power. Lawmakers have to oppose the abuse of power, also when it comes to salaries. Total freedom in the sphere of income clashes with notions of justice. ${ }^{21}$ The government must regulate and guide in such a way that the great disparity in welfare and income, together with the resulting impoverishment of a part of the (world) population, is resisted and reverted.

For this reason, some have favoured the establishment of maximum incomes. Accordingly, the so-called 'Declaration of Tilburg' (2008) of the Platform for a Sustainable and Solidary Economy (PDSE) includes the following amongst its focal points: ' $[B]$ y means of consultation and if necessary by regulation, an upper limit of net incomes should be introduced' (Platform DSE 2008). The economist, Bob Goudzwaard, who is one to have signed the declaration, even noted that this is a biblical notion. Pointing to Matthew 6:19 ('Do not store up for yourselves treasure on earth') and 1 Timothy 6:10 ('The love of money is the root of all evil'), he remarked that 'within a biblical trajectory this could even be seen as service to one's neighbour (albeit at first undoubtedly not a very welcome one)' (Goudzwaard 1976:254).

In the 'Declaration', it should be noted that a private rule for life has been turned too hastily into a duty enforced by authority. Yet, life is too variegated for imposing a universal income maximum, and too complicated for setting maximum incomes for each and every sector. Nor would it on a practical level be viable to establish a maximum net income by levying a tax of $100 \%$ on the income of high earners above a certain level, since people will always devise ways to circumvent that. Too much government legislation can lead to the erosion of our own sense of moral responsibility. If laws and rules are to be effective, it is necessary that they be embedded within a moral structure. Quite rightly, Douma (1986) argued that on a moral level we could indeed speak about maximum incomes, but that it is hardly possible to establish such maximums by law. Nor is it altogether impossible to manage a high income in a responsible, Christian manner. It is not the high income

21.A basic market framework plus the right kind of private and governmental activity to empower the poor is the best alternative known today. But that is very different from a pure laissez-faire of libertarian approach that rejects almost all government intervention in the economy' (Sider 2005:90). itself that is evil, but the unreasonable inequality in view of others. Monopolies, on the other hand, do need to be resisted (Douma 1986:144).

The government therefore has a twofold task. In the upper echelon it will have to oppose the abuse of an economic power position, whilst, at the other end of the spectrum, it must safeguard a minimum subsistence by establishing minimum wages by law and/or social regulation. The government need not aim at levelling incomes as such. At the same time, the way it levies taxes and social premiums (i.e. according to the ability-to-pay principle) will still have a levelling effect.

\section{Excursus: Roscam Abbing}

The Dutch ethicist, Pieter Roscam Abbing, published a lengthy book entitled Ethiek van de inkomensverdeling [The ethics of income distribution] 40 years ago. His point of departure for this book was justice and neighbour love. Whilst these may be the fruit of the Christian faith, Roscam Abbing was of the opinion that anyone who was not a Christian, but still did accept the calling to neighbour love could also accept his argument in full (Roscam Abbing 1973:28). Also, the notion of social justice is evident to all whose view has not been darkened by selfishness, regardless of whether that selfishness be rationalised in a coherent worldview or not. (Roscam Abbing 1973:141) Accordingly, his first precondition for an equitable income distribution is some sense of morality amongst the people (Roscam Abbing 1973:313). Following an extensive analysis of all factors that play a role in determining how incomes might be distributed equitably, Roscam Abbing arrives at a strict system of topdown regulation for income and prices. This is, in his view, the only way for the powers of socio-economic egoism to be restrained.

Roscam Abbing (1973) is very conscious in his choice to take his point of departure in communism:

It is appropriate to make the pursuit of social justice the primary concern, to entrust that pursuit to the government, and to give the government the power it needs to be successful in this pursuit. [...] It is in itself appropriate to make the goods of production the property of the community, and it is improper to reject this on ethical grounds. (p. 424)

Roscam Abbing is only interested in the socio-economic order of communion - 'in the warranted conviction that this order can be realised in an ideologically-pluriform and politicodemocratic state structure' (Roscam Abbing 1973:425). This order may, however, only be reached along the road of democracy, in the confidence of the power of conviction in one's own arguments (Roscam Abbing 1973:527).

Roscam Abbing (1973) acknowledged that his ideal could not yet be found anywhere in an unadulterated form:

Especially in countries that are ruled by communism this potentially viable socio-economic system is still fatally mixed 
with the altogether reprehensible one-party political system and with a horrendous historical-materialist worldview. (p. 529)

For this reason he wanted more scholarly research to be carried out.

Roscam Abbing did not sufficiently consider whether the socio-economic system of coercion that he proposes can really be separated from the political system of coercion he rejects. Communism is incompatible with intellectual freedom and democracy. It pursues an elevated moral principle (that Roscam Abbing also promotes), but it does so using immoral means. What is more, his ideal of equitability involves an underestimation of the real differences between people and of the indispensability of reward as a stimulus in an imperfect world. He fails to do justice to the personal responsibility human beings have as bearers of God's image in the choices they make by placing this responsibility altogether outside of their hands.

\section{The Christian church as a contrast-community}

Justice will never be perfect in human society. Even the government has only limited means available to stem the tides of greed and selfishness. This is why personal ethic remains indispensable as the final keystone. Christians have the calling to lead as examples, even if this has the consequence that they must forego a state of wealth that may indeed have been within their reach as human beings. They do this because they attach greater value to a clear conscience than they do to material riches. For what does anyone gain by winning the whole world at the cost of destroying himself (Lk 9:25)? By living such a life, they reflect something of the coming Kingdom of God, and show how valuable the virtue of modesty is, which is in fact important for all of society: 'Without transforming its own economy, the church cannot have much effect in its society's economy' (Meeks 1989:25). As Cavanaugh (2007) states:

The role of the church is not merely to make policy recommendations to the state, but to embody a different sort of politics, so that the world may be able to see a truthful politics and be transformed. The church does not thereby withdraw from the world but serves it, both by being the sign of God's salvation of the world and by reminding the world of what the world still is not. (p. 404)

The church is a community of faith where people learn to overcome their own interests and to break through group interests.

Where the government's social codes and laws reach the end of their possibilities, their church members can begin to address each other if greed manifests itself amongst them. Ronald Sider (2005:97) even asks, rhetorically: 'Would it not be more biblical to apply church discipline to people whose greedy acquisitiveness has led to "financial success" than to elect them to the board of elders?' One of the apostle Paul's requirements for elders and deacons is indeed that they not be lovers of money or money-grubbers (1 Tm 3:3, 8; Tt 1:7).
Those who enjoy a high income do not necessarily need to refuse it. They should, however, be well aware of the temptations that follow as a result ${ }^{22}$ The Bible calls them not to be proud or to place their hope in something as precarious as wealth and rather to place their trust in God, who richly provides us with everything for us to enjoy - indeed, to enjoy! - and to do good, to be rich in good deeds, generous and ready to help (1 Tm 6:17-18). This is how Christians can make a difference. By being consciously different, they will be as salt that gives society its taste (Mt 5:13).

\section{Acknowledgements Competing interests}

The author declares that he has no financial or personal relationship(s) that may have inappropriately influenced him in writing this article.

\section{References}

Babones, S., 2013, 'ILO: U.S. Inequality now literally off the chart', in Inequality.org, viewed 17 March 2014, from http://inequality.org/ilo-report-inequality-literallychart/

Biéler, A., 1961, La pensée économique et sociale de Calvin, Georg \& Cie S.A., Genève.

Cavanaugh, W.T., 2007, 'Church', in P. Scott \& W.T. Cavanaugh (eds.), The Blackwell Companion to Political Theology, pp. 393-406, Blackwell Publishing, Malden MA/ Oxford/Carlton.

Conijn, F., 2011, 'Alleen met geld valt geen geld te verdienen', Het Financieele Dagblad, 12 April, viewed 18 February 2015, from http://meetcpi.nl/index. php?page $=7 \&$ type $=2 \&$ id $=327$

De Bruijne, A.L.Th., 2011, 'Zonder het Oude Testament geen christelijk leven', De Reformatie LXXXVII, 80-83.

Douma, J., 1986, Vrede in de maatschappij - Een handreiking voor maatschappelijke vraagstukken, Gereformeerd Maatschappelijk Verbond, Zwolle.

Goudzwaard, B., 1976, Kapitalisme en vooruitgang, Van Gorcum, Assen/Amsterdam.

Goudzwaard, B., Van der Vennen, M., Van Heemst, D. \& Weigand-Timmer, J., 2007, Hope in troubled times, Baker Academic, Grand Rapids.

Krugman, P., 2011, 'Oligarchy, American Style', New York Times, 04 November, viewed 18 February 2015, from http://www.nytimes.com/2011/11/04/opinion/oligarchyamerican-style.html

Leibbrandt, M., Finn, A. \& Woolard, I., 2012, 'Describing and decomposing postapartheid income inequality in South Africa', Development Southern Africa 29(1) 19-34, viewed 15 September 2014, from http://www.tandfonline.com/doi/pdf/1 19-34, viewed 15 September 2014
$0.1080 / 0376835 X .2012 .645639$

Marxists Internet Archive n.d., Annotations at the program of the German Labour Party, viewed 11 September 2012, from http://www.marxists.org/nederland/ marty, viewgels/1875/1875gotha.htm

Meeks, M.D., 1989, God the economist - The doctrine of God and political economy, Fortress Press, Minneapolis.

Niebuhr, R., 1957, Love and justice - Selections from the shorter writings of Reinhold Niebuhr, Westminster/John Knox Press, Louisville.

O'Donovan, O., 2005, The ways of judgment, W.B. Eerdmans Publishing Company, Grand Rapids/Cambridge.

Oxfam International, 2014, Working for the few - Political capture and economic inequality, viewed 29 January 2014, from http://www.oxfam.org/sites/www. oxfam.org/files/bp-working-for-few-political-capture-economic-inequality200114-summ-en.pdf

Piketty, T., 2013, Le capital au XXIe siècle, Seuil, Paris.

Platform DSE, 2008, Verklaring van Tilburg, viewed 06 March 2014, from http://www. platformdse.org/verklaring-van-tilburg/

Roscam Abbing, J., 1973, Ethiek van de inkomensverdeling, Kluwer, Deventer.

Rousseau, J.-J., [1755] 1992, Discours sur l'origine et les fondements de l'inégalité parmi les hommes, GF Flammarion, Paris.

Sacks, J., 2003, The dignity of difference, Continuum, London/New York.

Sider, R.J., 2005, Rich Christians in an age of hunger - Moving from affluence to generosity, 5th edn., Thomas Nelson, Nashville.

Skidelsky, R. \& Skidelsky, E., 2012, How much is enough? Money and the good life, Other Press, New York.

Stiglitz, J., 2013, The price of inequality, Penguin, London.

22.Jesus once stated hyperbolically: 'It is easier for a camel to pass through the eye of a needle than for a rich man to enter the kingdom of God' (Lk 18:25; cf. $1 \mathrm{Tm}$ 6:9-10). 
Terreblanche, S., 2002, A history of inequality in South Africa 1652-2002, University of Natal Press, Pietermaritzburg.

The Economist, 2011, 'Inequality. The rich and the rest', viewed 18 February 2015 from http://www.economist.com/node/17959590

The Economist, 2013, 'Inequality. Growing apart', viewed 18 February 2015, from http://www.economist.com/news/leaders/21586578-americas-incomeinequality-growing-again-time-cut-subsidies-rich-and-invest

Timmermans, F., 2011, 'Wat ik Mark Rutte van harte gun', NRC Handelsblad, 30 November

Van Bruggen, J., 1990, Matteüs - Het evangelie voor Israël, Kok, Kampen.
Van Spanje, T.E., 2009, 2 Korinthiërs - Profiel van een evangeliedienaar, Kok, Kampen. Wikipedia, n.d., Code-Tabaksblat, viewed 26 August 2014, from nl.wikipedia.org/wiki/ Code-Tabaksblat

Wilkinson, R.G. \& Pickett, K., 2009, The spirit level: Why more equal societies almost always do better, Allen Lane, London.

World Economic Forum, 2014, Global Risks Ninth Edition - Geneva 2014, viewed 18 February 2015, from http://www3.weforum.org/docs/WEF_GlobalRisks_ Report_2014.pdf

Wright, C.J.H., 2004, Old Testament ethics for the people of God, InterVarsity Press, Nottingham. 